\title{
Model of engineering scheme for the organisation of construction life cycle contracts
}

\author{
Galina N. Shinkareva \\ Moscow State University of Civil Engineering (National Research University) (MGSU), \\ 26 Yaroslavskoe shosse, Moscow, 129337, Russian Federation
}

\begin{abstract}
Introduction. The question of increasing the efficiency of investment and construction projects in the life cycle of facilities on the basis of modern engineering schemes becomes of particular relevance during periods of economic crisis. A formalised description of a solution to this problem is proposed on the basis of an engineering scheme for the construction Life Cycle Contract (LCC) model. The engineering scheme model for the organisation of the construction Life Cycle Contract considers the distribution of limited material, technical and labour resources, depending on the class of importance of work performed and the cost of compensation for the negative impact of random factors.

Materials and methods. The methodical approach consisted of analysis and comparison of organisational structures of investment and construction activity, analysis of theory, practice and ways of improving the efficiency of modern engineering schemes for organising construction projects, methods of logical-semantic and simulation modelling and the published work of Russian and foreign scientists on the topic under study.

Results. The process of implementing investment and construction projects for Life Cycle Contracts is presented in the form of a model of the engineering scheme of the organisation of construction activity. In this model, important procedures for selecting options for organisational and technological solutions, as well as the assessment and allocation of resources for the work to be performed, are set out. The coefficient of importance for each type of work is determined by a mathematical method based on the method of nested scalar convolutions, based on Bohr's principle of complementarity and Gödel's incompleteness theorem, as well as by means of expert estimates on the normalised reversed scale.

Conclusions. An evaluation of the necessity for introducing complex engineering support to investment and construction projects throughout the life cycle is given with the maximum responsibility of the organiser of a construction project to the client under conditions of the greatest concentration of managerial powers. When the results of interaction between participants in the investment and construction process are predicted in various changing conditions, the practical use of the provisions proposed in the article makes it possible to adopt adequate management decisions that increase the efficiency not only of planning but also implementing construction projects. The results of the study can be applied in the development of recommendations for the formation of a new evaluation and regulatory framework, allowing indicators of the duration and cost of construction projects to be forecast considering the negative impact of random factors.
\end{abstract}

KEYWORDS: engineering scheme, organisation of construction, Life Cycle Contract, category of importance, average priority coefficients method, random factors, organiser of construction

FOR CITATION: Shinkareva G.N. Model of engineering scheme for the organisation of construction life cycle contracts. Vestnik MGSU [Proceedings of Moscow State University of Civil Engineering]. 2018; 13(10):1204-1210. DOI: 10.22227/19970935.2018.10.1204-1210

\section{Модель инжиниринговой схемы организации строительства для контрактов жизненного цикла}

\author{
Г.Н. Шинкарева \\ Национальный исследовательский Московский государственный строительный университет \\ (НИУ МГСУ), 129337, г. Москва, Ярославское шоссе, д. 26
}

\begin{abstract}
АННОТАЦИЯ
Введение. В период кризисных явлений в экономике особую актуальность приобретает тема повышения эффективности реализации инвестиционно-строительных проектов в перспективе жизненного цикла объектов на основе использования современных инжиниринговых схем организации строительства. Предлагается формализованное описание решения данной задачи на основе модели инжиниринговой схемы организации строительства для контрактов жизненного цикла, учитывающей распределение ограниченных материальнотехнических и трудовых ресурсов в зависимости от категории значимости выполняемых работ и затрат на компенсацию негативного воздействия случайных факторов.

Материалы и методы. Использован метод анализа и сопоставления организационных структур инвестиционностроительной деятельности, анализ теории, практики и путей повышения эффективности современных инжиниринговых схем организации строительства, методы логико-смыслового и имитационного моделирования, работы российских и зарубежных ученых по исследуемой теме.
\end{abstract}


Результаты. Процесс реализации инвестиционно-строительного проекта для контрактов жизненного цикла представлен в модели инжиниринговой схемы организации строительства как деятельность организатора строительства, при которой осуществляется увязка процедур отбора вариантов организационно-технологических решений, их оценки и распределения ресурсов между выполняемыми работами с учетом коэффиициента значимости, который для каждого вида работ определяется математическим методом на основе метода вложенных скалярных сверток, основанного на принципах дополнительности Н. Бора и теореме о неполноте К. Гёделя и посредством экспертных оценок по нормированной обращенной шкале.

Выводы. Дана оценка необходимости внедрения комплексного инжинирингового сопровождения инвестиционностроительных проектов на протяжении всего жизненного цикла с максимальной ответственностью организатора строительства перед заказчиком в условиях наибольшей концентрации управленческих полномочий. Использование на практике предложенных в статье положений, когда производится прогнозирование результатов взаимодействия участников инвестиционно-строительного процесса в различных меняющихся условиях, дает возможность принятия адекватных управленческих решений, повышающих эффективность не только планирования, но и реализации строительных проектов. Результаты проведенного исследования могут быть применены при разработке рекомендаций для формирования новой сметно-нормативной базы и прогнозных показателей продолжительности и стоимости объектов строительства с учетом отрицательного воздействия случайных факторов.

КЛЮчЕВЫЕ СЛОВА: инжиниринговая схема организации строительства, контракты жизненного цикла, категория значимости, метод усредненных коэффиициентов приоритета, случайные фракторы, организатор строительства

для цитировАния: Шинкарева Г.Н. Model of engineering scheme for the organisation of construction life cycle contracts // Вестник МГСУ. 2018. Т. 13. Вып. 9. С. 1204-1210. DOI: 10.22227/1997-0935.2018.10.1204-1210

\section{INTRODUCTION}

Under contemporary conditions of lack of investment and degradation of the traditional general contract form of construction, a special form of public-private partnership known as the Life Cycle Contract (LCC), analogous with foreign practices, is widely used in the Russian Federation in the implementation of infrastructure facilities. This format of interaction between the private agent and the state is one in which a contractor undertakes not only to construct a property, but also to continue to bear its operating costs, as well as to carry out disposal at the end of its service life; in turn, the client pays for the work of the contractor at determined stages of work. Within the Russian legal framework, an LCC is governed by Part 16 of Article 34 of the Law No. 44-FL "On Public Procurement". The terms governing conclusion of an LCC are regulated by the Decree of the Government of the Russian Federation No. 1087 of November 28, 2013. However, while this format of public-private partnership is undoubtedly beneficial for the state, it has not received a wide response from private investors due to the risks of underfunding, high transaction costs, as well as the limited material- and technical resources of private contractors. To increase the effectiveness of the Life Cycle Contract and reduce risks, it is proposed to use the engineering scheme of the construction organisation, which makes it possible to implement the investment and construction project within given time and cost constraints through the development of rational management decisions. By limiting the distribution of resources at the planning and feasibility study stages of investment and construction projects, while taking into account the priority of the works performed and the costs of compensating for the negative impact of random factors, contribute to more efficient utilisation of resources allocated to the construction of facilities and more accurate cost planning.

One of the key conditions for improving the quality of organisational and technological decisions, increasing the efficiency of its development and providing necessary justification, is the use of modern information technologies, including telecommunications and appropriate software, which form the basis of Building Information Modelling (BIM) technologies.

\section{Background}

It is possible to formulate a conclusion on increasing the efficiency of all stages of the life cycle of an property on the basis of modern engineering schemes of construction organisation [1-3], simulation modelling theory and system analysis in management [4-6], modelling of solutions of organisational and technological problems by the reliability criterion [7], assessment of the management effectiveness of the construction project implementation under the influence of random factors [8-10], ways of increasing construction productivity based on the use of complex contracts [11-13] and Life Cycle Contracts (LCCs) [18]. Analysis of publications in foreign sources on improving the efficiency of the investment and construction project at all stages of the life cycle $[5,15,16]$ confirms the need to further improve the theoretical and practical aspects of engineering activities for LCCs based on the theory of simulation and functional method using artificial intelligence and BIM technology [7, 17-19].

\section{MATERIALS AND METHODS}

The iterative modelling of various kinds of uncertainties is carried out by introducing correction indices formed on the basis of statistical sampling distributions, 
expert estimates, mathematical expectation and variance in order to solve the problem of selecting the optimum organisational and technological solution, taking the priority of the work performed into account as well as the costs of compensating for the negative impact of random factors. Identification of the probability of indicator deviation from terms and cost of the construction of a property is carried out from the set parameters according to the following scheme:

1. The maximum probability of performance of all types of works is revealed by conformity with established time constraints.

2. The greatest value of probability of performance of separate types of works within the limited cost parameters is defined.

3. Obtained results are compared with the rest of the criteria, as determined by the probability of realisation of the project.

The basic rules for identifying priorities for the work performed can be as follows:

1. A higher priority is the work that is located on the critical path of the calendar plan (network schedule) and is in the process of completion.

2. The priority of the work corresponds to the expected usefulness of its implementation in the total amount of work performed.

Thus, all works to be performed are divided into three categories according to their priority (importance):

1. Of high importance - the implementation of these works involves hazards including mechanical, fire - and, for particularly dangerous, technically complex and unique properties, industrial or radiation risks - which implies priority funding in full at this stage.

2. Of average importance - it is impossible to complete the construction of the property to the extent sufficient to start operation, provided that the minimum necessary safety requirements provided for No. 384-FL "Technical regulations on the safety of buildings and structures" can be fulfilled in the execution of these works. Financing and provision of resources is carried out in this period on a residual basis after meeting the needs of the work of the first group.

3. Of low importance - works that determine aesthetic perception and do not affect the safety of the property. These works cannot be financed at all in the main construction period of the facility; their implementation can, if necessary, be attributed to the initial stage of operation of the facility after the beginning of the effect (profit).

In the case of equal and sufficient funding, all works of average and low priority are implemented in full in accordance with the calendar plan (schedule) of construction.

Implementation of the project within the framework of the engineering management scheme is focused on the maximum responsibility of the contractor (organiser of construction) to the client, including the functions of coordinating the procedures for selecting options for the performance and evaluation of works and allocation of resources between them.

The concept of project-oriented management makes it possible to create new tools for regulating investment activities, which in turn make it possible to more accurately plan the cost of construction of properties, consider issues involved in their construction in a timely manner and determine the probability of exceeding these terms.

In this regard, the interaction between the organiser of construction and contracting companies takes place involving a large number of initial parameters: the time period and cost of construction, the range of material and technical and labour resources, indicators of production capacity of contractors, construction conditions, intensity and uniformity of resource consumption (financing), etc.

When developing organisational and technological documentation at the stage of preparation of construction, different solutions are compared and sequence of work stages determined taking the achievement of the greatest overall effectiveness into account. The proposed system of averaged priority coefficients organised by type of work, used in the calculation of scheduling and feasibility study of investment projects - especially when funding is limited - can serve as an effective tool to improve efficiency through the rational distribution of time and space allocated for the construction of resources.

The statement of the problem of selecting between alternative organisational-technological solutions and providing formal descriptions of their solution is proposed on the basis of the method of nested scalar convolutions $[8,9]$ based on Bohr's complementarity principle and Gödel's incompleteness theorem.

\section{RESULTS}

In general, the solution of the problem is represented by the formula:

$$
\{\{N\},\{Y\}\} \rightarrow N^{*},
$$

where $\{N\}-$ number of types of construction works; $Y$ - selection function (rule of priority setting); $N^{*}-$ selected priority types of construction works.

A multiplicity $\{N\}$ - list of types of construction works from which it is necessary to assign priority according to category.

When the function $Y$ is defined, the work parameter vectors are detailed and evaluated (for example: resources, duration, labour, machine capacity, time reserves, etc.), after which a decision is made based on the results of their comparison. The vector approach system is implemented by decomposing the function $Y$ into a population, leading to the definition of priori- 
ties in the structure of its indicators. The properties of all the works to be performed are preliminarily divided into priority categories from the first to the third and considered at a level whereby they can be conveniently compared. The task of establishing the criteria for alternative options can be expressed by a hierarchical system, where at the lower level an evaluation of individual works is performed on indicators determined by the vector of ranks, while, at the upper level, the level of importance of the work to be performed is assessed from the point of view of constructing the entire facility. Before this can be done, it is necessary to establish a list of evaluation criteria and assign them to appropriate hierarchical levels.

Qualitative characteristics (alternatives) of the performed works are established by a vector system of ranks

$$
y^{(i-1)}=\left\{y_{i}^{(i-1)}\right\}^{m_{i=1}^{(i-1)}} \cdot i \in[2, q],
$$

where $y^{(i-1)}$ - the vector of ranks at the $(I-1)-m$ level of hierarchy, which determines the qualitative parameters of alternatives at the $i$-m level; $q$ the number of hierarchical levels; $m^{(i-1)}$ — number of selection options $(i-1)$ - level. Quantitative characteristics of $m$ criteria $y^{(1)}=y$ of the first category of priorities for alternatives to the work performed are established. From this, we can conclude that $m^{(1)}=m$ and $m^{(q)}=1$.

The same selection criterion $(i-1)$ of the hierarchy level can be used to assess the importance of multiple indicators $+i$-level.

The same selection criterion $(i-1)$ of the hierarchy level can be used to assess the importance of multiple indicators $+i-1$ level. A set of individual coefficients are combined into a vector system of ranks

$$
K_{i p}^{(i-1)}=\left\{K_{i p}^{(i-1)}\right\}_{p=1}^{m^{(i)}}, i \in[2, q],
$$

where $K$ - coefficient of importance.

The system method adopted as a basis for solving the problem of choosing alternatives is reduced to the search for an analytical assessment of the $y^{*}$ rank vector and a qualitative assessment of the effectiveness of this choice; the best one is selected from the identified alternatives. At the same time, each of the alternatives is considered in the aggregate of all interrelated elements with different characteristics, different from the general parameters of the property.

The problem of selection of alternative organisational and technological solutions is proposed for solution using the method of nested scalar convolutions. An iterative sequence of actions of the scalar convolution of the average weighted vector criteria is constructed at each level of the hierarchy from the initial to the final, considering the vectors of ranks and the accepted scheme of compromises [2, 3].

$$
\left\{\left(y^{(i-1)}, K^{(i-1)}\right) \rightarrow y^{(i)}\right\}, i \in[2, q]
$$

where, at the same time, the evaluation of the efficiency of the adopted method of selection of alternatives by levels of hierarchy in a generalised form is represented by the solution of the problem of determining the scalar convolution of criteria at the final level of the hierarchy:

$$
y^{*}=y^{(i)}
$$

Under conditions of a rational choice of the scheme of compromises, it is possible to use a recurrent formula (4). The application of the method of nested scalar convolutions is preferable if a nonlinear scheme of compromises is used, in which all particular criteria must be nonnegative, minimised and limited, and the condition of generality of the hierarchy system as a whole must be observed:

$$
0 \leq y_{i} \leq B_{i}, B=\{\mathbf{B i}\}_{i=1}^{n},
$$

where $\mathbf{B}$ - vector of constraint of the parameters of the considered hierarchy level; $n$ - numerical index.

The evaluation of the considered property of the alternative at the $i-1$ level of the hierarchy, in accordance with the formula (4) and on the basis of a nonlinear scheme of compromises, is determined by the following expression

$$
Y_{p}^{(i)}=\sum_{i=1}^{n_{p}^{(i-1)}} k_{i p}^{(i-1)}\left[1-y_{0 p}^{(i-1)}\right], P \in\left[1, n^{(i)}\right],
$$

where the normalised parameters of the $(i-1)$ level are reduced to identity of multiplication. In this connection, $y_{0 p}^{(i-1)}$ - components of the normalised vector $y_{0}^{(i-1)}$, taking part in the evaluation of the considered property of the alternative at the $i-1$ level of the hierarchy; $n_{p}^{(i-1)}$ - number of options; $n^{(i)}$ - number of parameters to be evaluated at the $i-1$ level.

In essence, the coefficients of significance of $K$ are conventionally-accepted parameters, which should be considered from the point of view of a dual physical meaning: on the one hand, as indicators that express the subjective opinion of the decision-maker (organiser of

Table 1. Reversed interval-rank scale for determining the priority factors $K$

\begin{tabular}{l|c}
\hline The level of importance (rank) & Intervals of estimates $Y_{0}$ \\
\hline Low & $1.0 \ldots 0.6$ \\
\hline Average & $0.6 \ldots 0.2$ \\
\hline High & $0.20 \ldots 0.0$
\end{tabular}


construction) in the selection of alternative organisational and technological solutions; on the other hand, the coefficients of a meaningful regression model based on the concept of a nonlinear scheme of compromises. The coefficients $K$ at each level of the hierarchy are either calculated mathematically or established by expert estimates on an inverse scale that combines a scale of order (ranks) describing the categories of importance and the scale of intervals with the corresponding numerical characteristics (Table 1).

The range of permissible values of the coefficients of importance $K \in G_{k}$ is calculated by the simplex method:

$$
G_{k}=\left\{k \mid k_{i} \geq 0, \sum_{(i=1)}^{n} k_{i}=1\right\} .
$$

The indicated admissible set of the domain of definition is obtained by calculating the significance coefficients by the formula:

$$
\begin{gathered}
K_{i p}^{(i-1)}=\frac{j_{i_{v} p}}{\sum_{i_{v}=1}^{\left.m_{i p}-1\right)} j_{i_{v} p}}, \\
p \in\left[1, m^{(i)}\right], i \in[2, n],
\end{gathered}
$$

where $k_{i p}^{(i-1)} i_{v}$ - of the component of the priority vector of the criterion at the $(i-1)$-m level of the hierarchy in the calculation of the efficiency evaluation of the considered property $I-1$ level; $j_{p}$ — class of importance $i_{v}$ - property $(i-1)-$ level for the considered property $j$-level (determined by the organiser of construction on a standardised scale of assessments (Table 1).

A necessary condition for the reflection of the idea of the method of nested scalar convolutions by the formula (7) based on the recurrent formula (4) is the normalisation of the resulting expression $Y_{0 p}^{(i)} \in[0 ; 1]$ i.e. the formation of the relative criterion is minimised, with a limit value equal to zero.

Application of the method of nonlinear scheme of compromises allows normalisation of convolution (7) not by the maximum value, but by the minimum parameter, since the ideal values are zero for the minimised indicators. Expanding formula (10):

$$
Y_{0 p}^{(i)}=0, \forall i^{-} \in\left[1, n_{p}^{(i-1)}\right]
$$

by normalisation (8), we obtain $y_{p \min }^{(i)}=1$. As a result, the recurrent formula for determining the evaluation criteria for the selection of alternative options for levels of the hierarchy appears as follows:

$$
\begin{gathered}
Y_{0 p}^{(i)}=1-\left\{\sum_{i=1}^{n_{p}^{(i-1)}} k_{i p}^{(i-1)}\left[1-y_{0 p}^{(i-1)}\right]^{-1}\right\}, \\
P \in\left[1, n^{(i)}\right], i \in[2, m] .
\end{gathered}
$$

To convert the calculated data into linguistic descriptions of the criteria, the inverted interval-rank scale of class of importance is used as shown in Table 1.
Using the concept of the scale of grades and methods of evaluation of options in the selection of alternatives on an interval scale, the ranking is reversed in order to convert the calculated values of analytical data to appropriate linguistic descriptions of the criteria, determining the level of importance of performed work (Table 1).

In many projects, certain types of work must be completed in a shorter time, which may require additional costs. Therefore, the method of priority setting can be used in the preparation of project implementation calendar plans for the minimum possible time, not exceeding the maximum allowable cost.

Thus, firstly, if the specified parameters of the investment and construction project are changed in time and cost, the introduction of corrective priority coefficients will allow the most accurate time and cost of the construction of the property to be obtained.

Secondly, it is possible to determine the types of construction works that will give the greatest effect, if they are performed as a priority.

Thirdly, the developed method allows to establish the stages in the development of organisational and technological solutions for the construction of the property. In order to carry out works assigned to the high importance category, it is possible to plan the maximum provision of material resources, then assign the maximum values to these indicators in the calculations of the scheduling, and then set the terms and amounts for financing the remaining works in accordance with the hierarchy of selection criteria.

\section{CONCLUSION AND DISCUSSION}

A more accurate prediction of the results of investment and construction projects in terms of an engineering management scheme to assist the organiser of construction projects allows rational management decisions to be taken that increase not only planning efficiency but also the implementation of design decisions. Modern telecommunications and related software, which form the basis of BIM-technologies, contribute to better decisions, development efficiency and justification of implementation. The change in the specified parameters of investment and construction projects under the influence of random factors can be adjusted by the introduction of appropriate priority factors, which will allow the timing and cost of the construction of properties to be established as accurately as possible. In tandem with this, the types of construction works are determined whose implementation will allow the optimal outcome to be prioritised, stages established in the development of organisational and technological solutions for the construction of the property selected in accordance with the hierarchy of selection criteria. Otherwise, ignoring the negative impact of random factors can lead to a significant distortion of data in the development of predictive indicators of the duration and cost of the property 
development and hypertrophied simplification of the chosen implementation scheme for the investment and construction project. A currently promising direction of research is the possibility of using averaged priority coefficients by types of work, determined in the scheduling of the system with regard to their contribution to the final outcome, which can serve as a tool for increasing efficiency through the rational distribution of limited resources.

In addition, further research is possible in the development of methods for assessing the effectiveness of the engineering company (organiser of construction).

\section{REFERENCES}

1. Bozhko L.L. Effectiveness assessment of regulating influence in the sphere of near-boarder cooperation. Management issues. 2011; 1(14):14-20. (rus.).

2. Aziz D., Nawawi A.H., Ariff R.M. ICT evolution in facilities management (FM): Building information modelling (BIM) as the Latest Technology. Procedia - Social and Behavioral Sciences. 2016; 234:363-371.

3. Zou Y., Kiviniemi A., Jones S.W. A review of risk management through BIM and BIM-related technologies. Safety Science. 2017; 97:88-98.

4. Aleksanin A.V., Sborshchikov S.B. Assessment of economic efficiency of using new technologies, materials and solutions in energy saving projects. Vestnik $M G S U$ [Proceedings of Moscow State University of Civil Engineering]. 2009; 1:164. (rus.).

5. Voronin A.N., Ziatdinov Y.K., Kuklinsky M.V. Multi-criteria decisions: Models and methods. Kiev : NAU, 2011; 348 (rus.).

6. Voronin A.N. A method of multicriteria evaluation and optimization of hierarchical systems. Cybernetics and systems analysis. 2007; 43(3):384-390. DOI: 10.1007/s10559-007-0060-8.

7. Ginzburg A.V. BIM-technologies in the process of life cycle of construction projects. Information resources of Russia. 2016; 5(153):28-31. (rus.).

8. Ginzburg A.V., Ryzhkova A.I. Artificial intelligence capabilities for increasing organizational technological reliability of construction. Vestnik $M G S U$ [Proceedings of Moscow State University of Civil Engineering]. 2018; 13:1(112):7-13. DOI: 10.22227/19970935.2018.1.7-13 (rus.).

9. Ginzburg A.V. Building life cycle information modelling. Industrial and civil engineering. 2016; 9:6165. (rus.).

10. Gusakova E.A. Information modeling of life cycle of high-rise construction projects. Vestnik $M G S U$ [Proceedings of Moscow State University of Civil Engineering]. 2018; 13:1(112):14-22. DOI: 10.22227/19970935.2018.1.14-22 (rus.).
11. Zharov Ya.V. Accounting for the organizational aspects in the process of planning building production in the energy sector. Industrial and Civil Construction. 2013; 5:69-71. (rus.).

12. Zhuravlev P.A. Construction cost and its formation stages. Vestnik of Irkutsk State technical University. 2015; 9(104):174-178. (rus.).

13. Sborshchikov S.B., Lazareva N.V. Cost engineering as the basis for integration of the processes of planning, financing and pricing in investment and construction activity. Vestnik MGSU [Proceedings of Moscow State University of Civil Engineering]. 2015; 11:178185. DOI: 10.22227/1997-0935.2015.11.178-185 (rus.)

14. Sborshchikov S.B., Lazareva N.V., Zharov Ya.V. Mathematical description of information interaction in investment and construction activities. Vestnik MGSU [Proceedings of Moscow State University of Civil Engineering]. 2014; 5:170-175. DOI: 10.22227/1997-0935.2014.5.170-175 (rus.).

15. Malakhov V.I. [Contract modeling of investment and construction projects]. URL: https://www.cfin. $\mathrm{ru} / \mathrm{itm} / \mathrm{bpr} /$ project lifecycle process.shtml (rus.).

16. Sinenko S.A., Ivanov V.A., Efimov V.V. Specific [Features of organizing and conducting tender contract auctions in the course of implementating investment-construction projects]. Scientific Review. 2017; 13:104-107. (rus.).

17. Churbanov A.E., Shamara Yu.A. The impact of information modelling technology on the development of investment construction process. Vestnik MGSU [Proceedings of Moscow State University of Civil Engineering]. 2018; 13:7(118):824-835. DOI: 10.22227/1997-0935.2018.7.824-835 (rus.).

18. Shinkareva G.N., Maslova L.A. Life cycle contracts: new format of interaction between the state, engineering companies and business. Scientific review. 2016; 18:222-227. (rus.).

19. Alrinia Z.S. BIM as a computer-aided design methodology in civil engineering. Journal of Software Engineering and Applications. 2017; 10:194-210. DOI: 10.4236/jsea.2017.102012. 
Aвоut the author: Galina N. Shinkareva - postgraduate student of the Department of information systems, technologies and automation in construction, Moscow State University of Civil Engineering (National Research University) (MGSU), 26 Yaroslavskoe shosse, Moscow, 129337, Russian Federation, ShinkarevaGN@mgsu.ru.

\section{ЛИТЕРАТУРА}

1. Божко Л.Л. Оценка эффективности регулирующего воздействия в сфере приграничного сотрудничества // Вопросы управления. 2011. № 1 (14). C. 14-20.

2. Aziz D., Nawawi A.H., Ariff R.M. ICT evolution in facilities management (FM): Building Information Modelling (BIM) as the latest technology // Procedia — social and behavioral sciences. 2016. No. 234. Pp. 363-371.

3. Zou Y., Kiviniemi A., Jones S.W. A review of risk management through BIM and BIM-related technologies // Safety Science. 2017. No. 97. Pp. 88-98.

4. Алексанин А.В., Сборщиков С.Б. Оценка экономической эффективности использования новых технологий, материалов и решений в проектах по энергосбережению // Вестник МГСУ. 2009. № 1. C. 164-167.

5. Воронин А.Н., Зятдинов Ю.К., Куклинский M.B. Многокритериальные решения: модели и методы. Киев : НАУ, 2011. 348 с.

6. Voronin A.N. A method of multicriteria evaluation and optimization of hierarchical systems // Cybernetics and systems analysis. 2007. Vol. 43. Issue 3 . Pp. 384-390. DOI: 10.1007/s10559-007-0060-8

7. Гинзбург A.B. В1М-технологии на протяжении жизненного цикла строительного объекта // Информационные ресурсы России. 2016. № 5 (153). С. 28-31.

8. Гинзбург А.В., Рыжкова А.И. Возможности искусственного интеллекта по повышению организационно-технологической надежности строительного производства // Вестник МГСУ. 2018. T. 13. Вып. 1 (112). C. 7-13. DOI: 10.22227/19970935.2018.1.7-13

9. Гинзбург А.В. Информационная модель жизненного цикла строительного объекта // Промышленное и гражданское строительство. 2016. № 9. C. 61-65.

10. Гусакова Е.А. Информационное моделирование жизненного цикла проектов высотного строительства // Вестник МГСУ. 2018. Т. 13. Вып. 1 (112). C. 14-22. DOI: 10.22227/1997-0935.2018.1.14-22
11. Zharov Ya.V. Accounting for the organizational aspects in the process of planning building production in the energy sector // Industrial and civil construction. 2013; 5:69-71.

12. Журавлев П.А. Цена строительства и этапы ее формирования // Вестник ИрГТУ. 2015. № 9 (104). C. $174-178$.

13. Сборщчиков С.Б., Лазарева Н.В. Стоимостной инжиниринг как основа интеграции процессов планирования, финансирования и ценообразования в инвестиционно-строительной дятельности // Вестник МГСУ. 2015. № 11. С. 178-185. DOI: 10.22227/1997-0935.2015.11.178-185

14. Сборщиков С.Б., Лазарева Н.В., Жаров Я.В. Математическое описание информационного взаимодействия в инвестиционно-строительной деятельности // Вестник МГСУ. 2014. № 5. С. 170-175. DOI: 10.22227/1997-0935.2014.5.170-175

15. Малахов В.И. Контрактное моделирование инвестиционно-строительных проектов. URL: https:// www.cfin.ru/itm/bpr/project_lifecycle_process. shtml

16. Синенко С.А., Иванов В.А., Ефимов В.В. Особенности организации и проведения конкурсных подрядных торгов при реализации инвестиционностроительных проектов // Научное обозрение. 2017. № 13. С. 104-107.

17. Чурбанов А.Е., Шамара Ю.А. Влияние технологии информационного моделирования на развитие инвестиционно-строительного процесса // Вестник МГСУ. 2018. Т. 13. Вып. 7 (118). С. 824-835. DOI: $10.22227 / 1997-0935.2018 .7 .824-835$

18. Шинкарева Г.Н., Маслова Л.А. Контракты жизненного цикла - новый формат взаимодействия государства, инжиниринговых компаний и бизнеса // Научное обозрение. 2016. № 18. С. 222-227.

19. Alcmia Z.S. BIM as a computer-aided design methodology in civil engineering // Journal of software engineering and applications. 2017. No. 10. Pp. 194210. DOI: $10.4236 /$ jsea.2017.102012.

\section{Поступила в редакиию 10 августа 2018 г.}

Принята в доработанном виде 7 сентября 2018 г.

Одобрена для публикачии 28 сентября 2018 г.

О в А в т о Р Е : Шинкарева Галина Николаевна - аспирант кафедры информационных систем, технологий и автоматизации в строительстве, Национальный исследовательский Московский государственный строительный университет (НИУ МГСУ), 129337, г. Москва, Ярославское шоссе, д. 26, ShinkarevaGN@mgsu.ru. 